論文

하이브리드 섬유로 보강한 고강도 경량 시멘트 복합체의 개발

방진욱, 김정수 ${ }^{* *}$ 이방연 ${ }^{* * *}$, 장영일 ${ }^{* * * *}$, 김윤용 ${ }^{* * *+}$

\title{
Development of Hybrid Fiber-reinforced High Strength Lightweight Cementitious Composite
}

\author{
Jin-Wook Bang ${ }^{*}$, Jung-Su Kim ${ }^{* *}$, Bang-Yeon Lee ${ }^{* * *}$, Young-Il Jang ${ }^{* * * *}$, Yun-Yong Kim ${ }^{* * * *+}$
}

\begin{abstract}
The purpose of this paper is to develop a Hybrid Fiber-reinforced High Strength Lightweight Cementitious Composite (HFSLCC) incorporated with lightweight filler and hybrid fibers for lightness and high ductility. Optimal ingredients and mixture proportion were determined on the basis of the micromechanical analysis and the steady-state cracking theory considering the fracture characteristics of matrix and the interfacial properties between fibers and matrix. Then 4 mixture proportions were determined according to the type and amount of fibers and the experiment was performed to evaluate the mechanical performance of those. The HFSLCC showed 3\% of tensile strain, 4.2MPa of ultimate tensile stress, $57 \mathrm{MPa}$ of compressive strength and $1,660 \mathrm{~kg} / \mathrm{m}^{3}$ of bulk density. The mechanical performance of HFSLCC incorporated with PVA fibers of 1.0 Vol.\% and PE fibers of 0.5 Vol.\% is similar to those of the HFSLCC incorporated with fibers of $2.0 \mathrm{Vol} . \%$.
\end{abstract}

\section{초 록}

이 논문의 목적은 경량 충진재와 하이브리드 섬유를 사용하여 경량성과 인장변형 성능이 우수한 섬유보강 고강도 경량 시멘 트 복합체(HFSLCC)를 개발하는 것이다. 이를 위하여 마이크로역학과 다수의 미세균열이 발생하기 위한 조건인 안정상태 균열 이론을 바탕으로 시멘트 매트릭스의 파괴 특성과 섬유-시멘트 매트릭스 경계 특성을 파악하여 사용재료 및 최적 혼입률을 결정 하였으며, 섬유 종류와 양에 따라 4가지 배합을 결정하였다. 4가지 배합으로 제조한 실험체는 실험을 통하여 역학적 특성(직접 인장, 압축강도, 단위질량)을 검증하였다. 검증 결과 4가지 배합으로 제조한 모든 섬유보강 고강도 경량 시멘트 복합체는 변형률 경화거동을 보였으며, 역학 성능은 평균 변형률 약 $3.0 \%$, 최대인장강도 약 $4.2 \mathrm{MPa}$, 단위질량 및 압축강도는 각각 약 $1,660 \mathrm{~kg} / \mathrm{m}^{3}$ 와 $57 \mathrm{MPa}$ 를 나타내었다. 또한 PVA섬유 $1.0 \%$ 와 PE섬유 $0.5 \%$ 를 혼입한 경우 섬유 사용량이 적으면서 $2.0 \%$ 섬유가 혼입된 복 합체와 유사한 성능을 나타내었다.

Key Words : 경량 충진재(Lightweight filler), 하이브리드 섬유(Hybrid fibers), 마이크로역학(Micromechanics), 변형률 경화거동 (Strain hardening behavior)

\section{1. 서 론}

콘크리트 구조물의 고층화, 대형화 및 장지간(long-span)화
됨에 따라 고성능 복합 신재료의 필요성이 대두되고 있다[1]. 특히 재료의 경량화 및 고강도화는 구조물의 자중감소를 위하 여 필수조건이며, 이 조건을 충족시키는 구조용 고강도 경량

* 충남대학교 토목공학과 석사과정

** 한화건설 기술연구소 선임연구원

*** University of Michigan 토목공학과 박사 후 연구원

**** 충남대학교 토목공학과 박사 후 연구원

*****+ 충남대학교 토목공학과 교수, 교신저자(E-mail:yunkim@cnu.ac.kr) 
콘크리트에 대한 연구가 많은 연구자들에 의해 수행되었다 [2][3]. 일반적으로 경량 콘크리트의 단위질량은 $300 \sim 2,000 \mathrm{~kg} / \mathrm{m}^{3}$ 정도이기 때문에 효율적으로 부재단면을 설계한다면, 구조물 의 자중이 감소하여 기초 공사비 및 재료비 등의 건설비용을 절감시킬 수 있을 뿐만 아니라 최근 국내·외에서 대두되고 있 는 지진에 대한 안전성 확보에도 유리한 장점이 있다. 그러나 고강도 경량 콘크리트는 상대적으로 취성적인 재료 특성을 나 타내기 때문에 균열 저항성 및 피로성능이 현저히 감소하여 콘크리트 구조물의 성능을 조기에 저하시키는 요인으로 작용 할 수 있다. 따라서 최근 고강도 경량 콘크리트의 인성 (toughness)을 증대시키기 위하여 시멘트 매트릭스에 단섬유를 혼입한 섬유보강 고강도 경량 콘크리트에 대한 연구[4][5]가 이루어지고 있으나 변형률 경화거동을 보이는 섬유보강 고강 도 경량 콘크리트에 대한 연구는 미흡한 실정이다. 따라서 이 연구에서는 변형률 경화거동을 보이는 하이브리드 섬유보강 고강도 경량 시멘트 복합체 (Hybrid Fiber-reinforced High Strength Lightweight Cementitious Composite, 이하 HFSLCC)를 개 발하고 그역학적 특성을 파악하고자 한다.

Fig. 1은 이 연구의 연구수행 과정 및 수행한 연구내용을 전체적으로 나타낸 개념도이다. 최적의 유동성과 섬유분산성, 경량성을 나타낼 수 있도록 사용재료를 결정하였으며, HFSLCC 의 섬유-시멘트 매트릭스 경계특성과 시멘트 매트릭스 파괴특 성을 파악하는 마이크로역학과 안정상태 균열이론[6]을 도입하 여 변형률 경화거동과 다중균열이 발생할 수 있도록 마이크로 역학 설계를 실시하였다. 이론적인 방법으로 예측한 마이크로역 학 설계의 타당성을 검증하기 위하여 역학적 실험을 실시하여 복합재료의 경량성, 인장성능, 강도를 평가하였다.

\section{2. 사용재료 및 시험방법}

\section{1 사용재료}

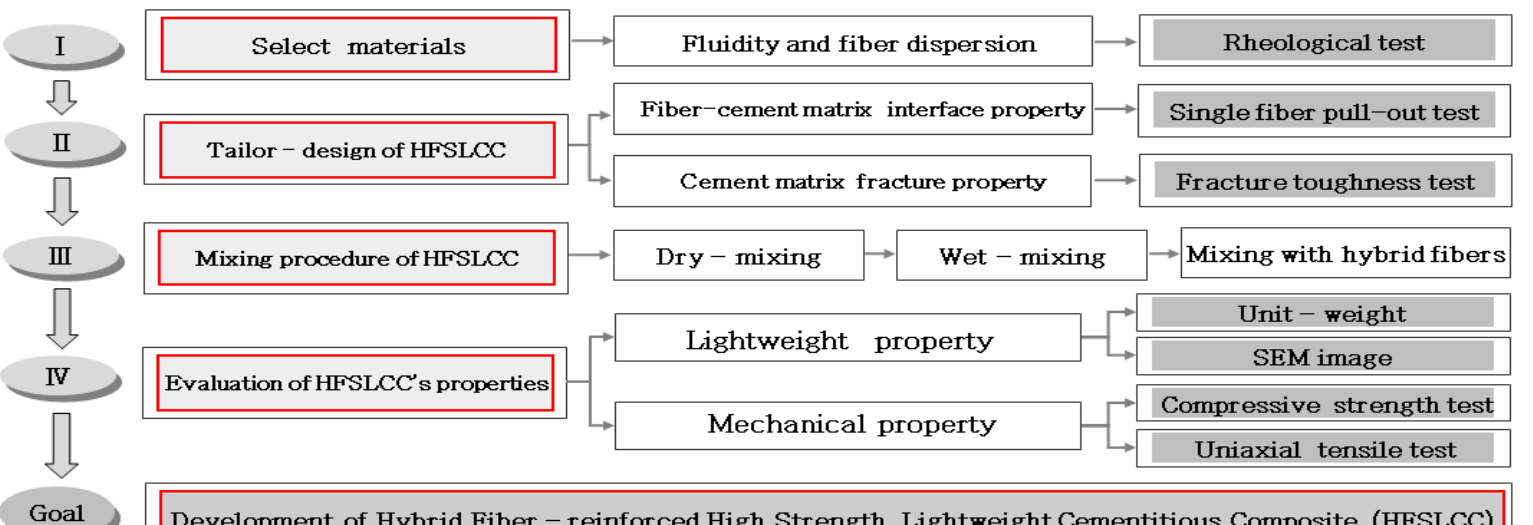

Fig. 1 The schematic outline for developing HFSLCC. 하였으며, Glass bubble과 고로슬래그 미분말을 충진재로 사용 하였다.

HFSLCC를 제조할 때 골재는 규사를 사용하였으며, 폴 리카르복실계 고성능 감수제(PCSP)와 셀룰로즈계 분리저감 제(HPMC)를 혼화제로 사용하였다. 또한 보강용 하이브리드 섬유로는 친수성 PVA섬유와 소수성 $\mathrm{PE}$ 섬유를 사용하였다.

\section{2 레올로지 실험}

시멘트 페이스트나 콘크리트의 슬럼프 등의 유동 특성은 항복응력과 관련이 있으며, 레올로지 실험을 통해 구할 수 있는 항복응력 값을 비교함으로써 굳지 않은 콘크리트의 유 동 특성을 평가할 수 있다고 알려져 있다[7].

고로슬래그 미분말은 섬유보강 시멘트 복합체의 유동성과 장기강도 증진에 효과적이라고 알려져 있다[8]. 이에 따라 이 연구에서는 고로슬래그 미분말의 최적 혼입률을 결정하기 위 해 레올로지 실험을 수행하였으며, 혼입률(시멘트 질량의 $15 \%, 25 \%, 35 \%$ 첨가)에 따른 항복응력을 평가하였다. 레올 로지 실험은 $\mathrm{B}$ 사의 회전점도계를 사용하였고, 스핀들 회전속 도를 내부 시멘트 매트릭스 $(W / C=50 \%)$ 점도가 선형 점탄성 범위 이내가 되도록 조절하였다.

\section{3 파괴인성 실험 및 섬유인발 실험}

마이크로역학 설계변수를 도출하기 위하여 매트릭스 파괴인 성 실험과 섬유인발 실험을 실시하였다. 수직하중과 함께 롤러 와 쐐기가 접하는 위치에서의 균열개구변위를 클립 게이지로 측정하여 파괴인성을 산출하였다. 또한 $\mathrm{PVA}$ 섬유와 $\mathrm{PE}$ 섬유에 대하여 섬유인발 실험을 실시하여 섬유-매트릭스 경계면의 화 학적 부착 $\left(G_{d}\right)$ 및 마찰 부착 $\left(\tau_{0}\right)$ 등의 변수를 구하였다. 섬유인 발 실험 장치 상세는 Fig. 2에 나타낸 바와 같다. 섬유인발 실 험을 위하여 실험체의 윗면을 정착장치에 부착하였으며, 돌출된 


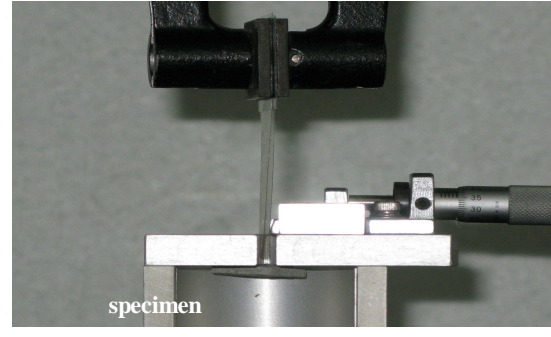

Fig. 2 Setup for single fiber pullout test.
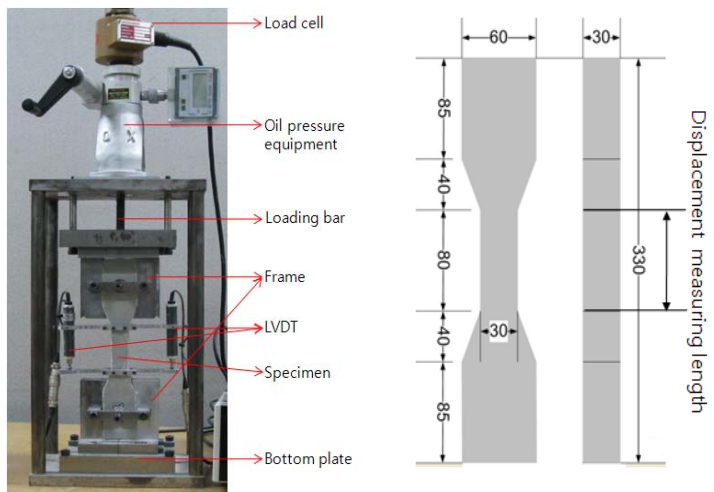

Fig. 3 Set-up for uniaxial tensile test and the specimen geometry.

섬유는 연신율로 인한 하중의 저하를 방지하기 위하여 아크릴 필름으로 감싼 후 상부 고정장치에 부착하였다. $0.2 \mathrm{~mm} / \mathrm{min}$ 의 인발 속도를 유지하고 변위제어 방식으로 실험을 수행하였으며, 인발 하중을 $10 \mathrm{~N}$ 용량의 로드셀로 측정하였다. 파괴인성 실험 과 섬유인발 실험에 관한 내용은 본 연구진에서 사전수행한 연 구[8]에 자세히 기술한바 있다.

\section{4 단위질량 시험}

본 연구에서 HFSLCC의 경량성을 검토하고자, "KS F 2409 굳지 않은 콘크리트의 단위용적질량 측정 방법”으로 시험을 실시하였다.

\section{5 압축강도 시험}

HFSLCC의 압축강도는 KS F 2403 콘크리트 압축강도 시 험 방법에 따라 제작된 $\phi 100 \times 200 \mathrm{~mm}$ 의 원주형 공시체를 28 일 수중양생 후 만능재료 시험기를 사용하여 측정하였다.

\section{6 직접인장 실험}

HFSLCC의 변형률 경화거동을 검증하기 위하여 직접인장 실험을 실시하였다. 실험체는 각각의 배합 조건에 따라 3 개 씩 재작하였으며, Fig. 3과 같이 단부 파괴를 방지하면서 실 험체에 균일한 하중이 가해지도록 아령형상으로 제작하였다.
모든 실험체는 28 일 수중양생 후 최대 용량이 $10 \mathrm{kN}$ 인 직접 인장 실험 장치를 이용하여 하중을 가한 후 로드셀을 이용하 여강도를 측정하였다. 변형률은 실험체 중앙부에 2 개의 변위 계(LVDT)를 설치하여 측정하였다.

\section{HFSLCC의 마이크로구조 이론적 설계}

\subsection{HFSLCC의 마이크로역학 설계 개념}

$\mathrm{Li}$ 등[6]에 따르면 다수의 균열과 변형률 경화거동을 보 이는 HFSLCC를 설계하기 위해서는 2가지 조건을 만족해야 한다고 언급한 바 있다. 그 첫 번째 조건은 식 (1)의 보상 에너지(complimentary energy, $J_{b}^{\prime}$ )가 시멘트 매트릭스 파괴인 성 즉, 균열선단의 인성 $\left(J_{t i p}\right)$ 보다 커야한다는 에너지 조건이 다(식 (2)). 여기서 $E_{c}$ 는 매트릭스 탄성계수이며, $K_{m}$ 은 시멘 트 매트릭스의 파괴인성이다. 이 조건이 만족 될 경우 HFSLCC는 응력하에서 일정한 균열폭을 가진 다수의 미세균 열이 발생하게 된다.

두 번째 조건은 최대 균열면 가교응력 $\left(\sigma_{0}\right)$ 이 인장 균열응 력 $\left(\sigma_{f c}\right)$ 보다 커야 한다는 강도 조건이다 (식 (3)). 이 조건을 만족하지 못하면 초기균열 후 섬유의 뽑힘이나 파괴에 의한 즉각적인 응력 저하가 발생하며 다중 균열이 발생하지 못하 고 국부파괴가 발생하게 된다.

$$
\begin{aligned}
& J_{t i p} \leqq \sigma_{0} \delta_{0}-\int_{0}^{\delta_{0}} \sigma\left(\delta_{0}\right) d \delta \equiv J_{b}^{\prime} \\
& J_{t i p}=\frac{K_{m}^{2}}{E_{c}} \\
& \sigma_{f c}<\sigma_{0}
\end{aligned}
$$

따라서 HFSLCC의 설계를 위한 에너지 조건과 강도 조건 을 평가하기 위해서는 $J_{b}^{\prime}$ 와 $\sigma_{0}$ 를 구하는 것이 필수적이며, 이러한 값들은 섬유의 뽑힘길이 $(\delta)$ 와 저항하중 $(P(\delta))$ 의 관계 를 나타내는 식 (4)와 섬유의 함유량 $\left(V_{f}\right)$, 섬유의 방향성에 대한 확률 $(p(\phi))$ 과 매입길이에 대한 확률 $(p(z))$ 등을 고려한 섬유 뽑힘으로 인하여 발생된 균열폭( $\delta$ )과 균열면에서의 응력 $(\sigma)$ 과의 관계인 식 (5) 등을 통하여 이론적으로 예측할 수 있 다. $J_{b}^{\prime}$ 를 구하기 위하여 우선 섬유인발 실험과 시멘트 매트 릭스의 파괴역학적변수를 이용하여 단일 섬유가 균열면에서 뽑히게 될 때의 $\delta$ 와 그 때의 $P(\delta)$ 와의 관계를 구해야 한다.

$$
\begin{aligned}
P(\delta) & =\sqrt{\frac{\pi^{2} E_{f} d_{f}^{3} \tau_{0}(1+\eta)}{2} \delta+\frac{\pi^{2} E_{f} d_{f}^{3} G_{d}(1+\eta)}{2}} \\
\sigma_{0}(\delta) & =\frac{4 V_{f}}{\pi d_{f}^{2}} \int_{\phi=0}^{\phi=\pi / 2}\left[\int_{z=0}^{z=\left(L_{f} / 2\right) \cos \phi} P(\delta) p(\phi) p(z) d z\right] d \phi
\end{aligned}
$$




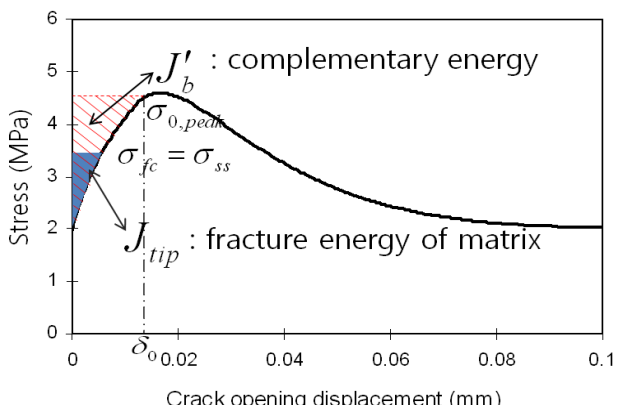

Fig. 4 Typical $\sigma-\delta$ curve for a strain hardening composite.

Table 1 Mixture proportions for fracture toughness test

\begin{tabular}{c|c|c|c|c|c|c}
\hline \hline $\mathrm{C}$ & $\mathrm{W}$ & $\mathrm{S}$ & Slag & GB & HPMC & PCSP \\
\hline \multirow{3}{*}{1.0} & \multirow{3}{*}{0.45} & \multirow{2}{*}{0.8} & \multirow{2}{*}{0.25} & 0.15 & 0.002 & 0.02 \\
& & & & 0.25 & 0.002 & 0.03 \\
& & & & 0.15 & 0.002 & 0.005 \\
\multirow{2}{*}{1.0} & \multirow{2}{*}{0.55} & \multirow{2}{*}{0.8} & \multirow{2}{*}{0.25} & 0.25 & 0.002 & 0.01 \\
& & & & 0.35 & 0.002 & 0.02 \\
\hline
\end{tabular}

C : Cement, W : Water, S : Silica sand, GB : Glass bubble

PCSP : Polycarboxylate super-plasticizer,

HPMC : Hydroxypropylmethyl-cellulose.

All numbers are mass ratios of cement weight.

여기서, $\eta=V_{f} E_{f} / V_{m} E_{m}$ 이며, $E_{f}$ 와 $E_{m}$ 은 각각 섬유와 시멘트 매트릭스의 탄성계수, $V_{f}$ 및 $V_{m}$ 은 각각 섬유와 시 멘트 매트릭스의 부피비, $d_{f}$ 는 섬유의 직경, $\tau_{0}$ 는 마찰 부착 응력, $G_{d}$ 는 화학적 부착응력이다. $P(\delta)$ 를 구한 후 균열면에 서의 $\sigma$ 를 구하기 위해 식 (5)에 나타낸 바와 같이 $P(\delta)$ 를 모두 적분하여 최종적으로 Fig. 4 의 $\sigma-\delta$ 와의 관계를 통하여 $J_{b}^{\prime}$ 와 $\sigma_{0}$ 를 구할 수 있다.

마이크로역학의 이론에 관한 수식전개와 자세한 내용은 Lin 등[9]의 연구에 의해 자세히 소개되어진 바 있다.

\subsection{HFSLCC의 최적 사용재료 결정}

3.2.1 충진재

HFSLCC의 경량성 확보와 시멘트 매트릭스 유동성 및 장기 강도증진을 위해 두 가지 충진재를 사용하였다. 경량 충진재 glass bubble은 밀도 $0.6 \mathrm{~g} / \mathrm{cm}^{3}$, 평균입경 약 $30 \mu \mathrm{m}$ 로 Fig. 5(a) 에서 볼 수 있듯이 유리질 막으로 쌓인 중공상태의 구 형태 를 띄고 있다. Glass bubble의 최적 혼입률을 결정하기 위해 Table 1 과 같이 2 가지 범위의 물-시멘트비에 시멘트 질량의 $15 \%, 25 \%, 35 \%$ 를 각각 첨가하였으며, 단위질량 실험과 파 괴인성 실험을 실시한 결과를 Table 2에 나타내었다. Glass bubble 혼입률이 증가할수록 단위중량이 감소하여 경량화에

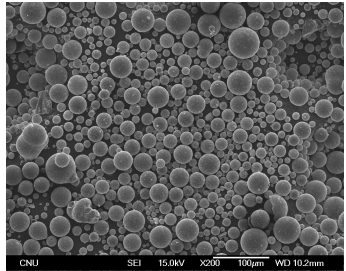

(a) Glass bubble

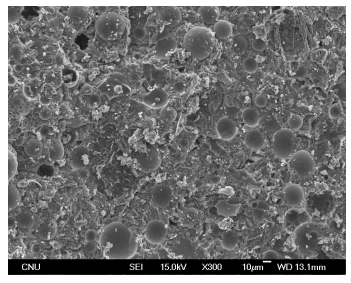

(c) Glass bubble contents $25 \%$

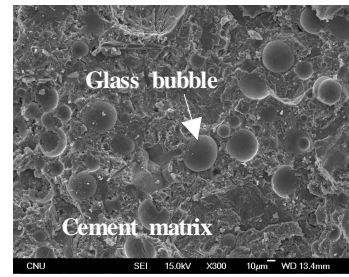

(b) Glass bubble contents $15 \%$

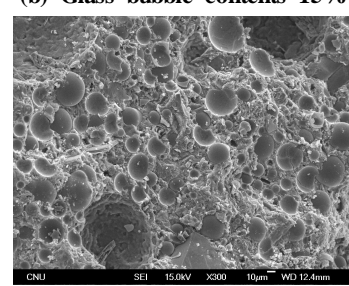

(d) Glass bubble contents $35 \%$
Fig 5 Glass bubble SEM image.

Table 2 Result of density and fracture toughness test

\begin{tabular}{c|c|c|c}
\hline \hline $\begin{array}{c}\text { W/C } \\
(\%)\end{array}$ & $\begin{array}{c}\text { GB/C } \\
(\%)\end{array}$ & $\begin{array}{c}\text { Bulk density } \\
\left(\mathrm{kg} / \mathrm{m}^{3}\right)\end{array}$ & $\begin{array}{c}\text { Fracture } \\
\text { toughness }\left(K_{m}\right) \\
(\mathrm{MPa} \cdot \sqrt{m})\end{array}$ \\
\hline \multirow{3}{*}{45} & 15 & 1,780 & 0.31 \\
& 25 & 1,690 & 0.26 \\
& 35 & 1,590 & 0.21 \\
\hline \multirow{3}{*}{55} & 15 & 1,700 & 0.28 \\
& 25 & 1,620 & 0.20 \\
& 35 & 1,500 & 0.16 \\
\hline
\end{tabular}

효과적임을 알 수 있다. 또한 파괴인성 역시 감소함을 알 수 있는데 이에 대한 내용은 $3.3 \mathrm{HFSLCC}$ 의 설계 절에서 자세히 다루도록 하겠다.

또한 일반 충진재로 밀도 $2.64 \mathrm{~g} / \mathrm{cm}^{3}$, 분말도 $4,300 \mathrm{~cm}^{2} / \mathrm{g}$ 의 국내 $\mathrm{H}$ 사의 고로슬래그 미분말을 사용하였다. 레올로지 실험 을 통하여 혼입률을 결정하였으며, Fig 6과 같이 시멘트 질 량의 $25 \%$ 를 첨가할 경우 항복강도가 가장 낮게 측정되어 유 동특성이 가장 우수한 것으로 나타나 혼입률을 $25 \%$ 로 결정 하였다.

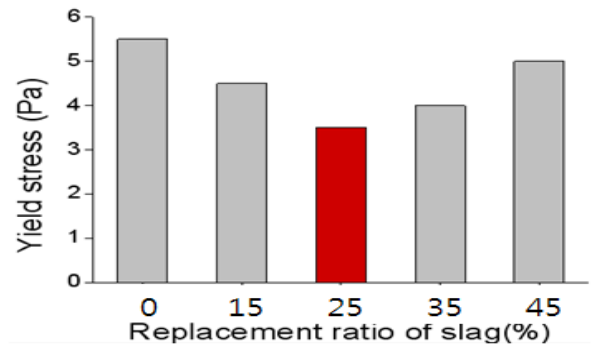

Fig. 6 Result of heological test for slag. 


\subsection{2 골재}

HFSLCC에 사용되는 최적의 골재로 평균입경 $130 \mu \mathrm{m}$, 밀 도 $2.65 \mathrm{~g} / \mathrm{cm}^{3}$ 인 국내에서 생산되는 규사를 사용하였다. 규사는 일반 강모래에 비해 $J_{t i p}$ 을 낮출 수 있고[10], Lepech 등[11] 의 연구에서 밝혀진 섬유 복합체의 유동성과 섬유분산성을 저하시키지 않는 골재 최대 크기 $200 \mu \mathrm{m}$ 를 초과하지 않기 때 문에 HFSLCC에 적용할 경우 최적의 유동 성능을 나타낼 것 으로 판단된다.

\subsection{3 하이브리드 섬유}

이 연구에서 사용되는 하이브리드 섬유로 일본 $\mathrm{K}$ 사의 상 용화된 PVA섬유와 PE섬유를 사용하였으며, 그 물리적 특징 을 Table 3에 나타내었다. HFSLCC 개발에 있어 탄성계수, 인장강도, 길이 등의 물리적 특성들은 마이크로역학에 의하 여 섬유 가교 특성을 예측·평가하는데 필요한 주요변수로 활 용되며, 물리적 특성이 서로 다른 하이브리드 섬유를 사용할 경우 PVA섬유가 다수의 미세균열을 유도하고 $\mathrm{PE}$ 섬유가 균 열폭이 큰 주균열을 제어함으로서 HFSLCC의 인장성능을 효 과적으로 증진시킬 수 있을 것이라 판단된다.

한편 기존 연구[6]에 따르면 친수성 단일 PVA섬유를 사 용할 경우 시멘트 매트릭스 전체 부피의 $2 \%$ 정도의 혼입이 인장성능 측면이나 비빔성능 측면에서 최적으로 밝혀진 바 있으나, 이 연구에서는 물리적 특성이 상대적으로 PVA섬유 보다 뛰어나지만 물과의 친화력이 떨어지는 소수성 $\mathrm{PE}$ 섬유 의 사용으로 인한 비빔성능과 인장성능 향상을 고려하여 Table 4와 같이 혼입률을 설정하였으며, 혼입률 변화에 따른 $\sigma-\delta$ 와의 관계를 도출하는 마이크로역학적 설계를 실시하였다.

Table 3 Physical properties of hybrid fibers

\begin{tabular}{c|c|c|c|c|c}
\hline \hline $\begin{array}{c}\text { Hybrid } \\
\text { fibers }\end{array}$ & $\begin{array}{c}\text { Elastic } \\
\text { modulous } \\
(\mathrm{GPa})\end{array}$ & $\begin{array}{c}\text { Length } \\
(\mathrm{mm})\end{array}$ & $\begin{array}{c}\text { Diameter } \\
(\mu \mathrm{m})\end{array}$ & $\begin{array}{c}\text { Tensile } \\
\text { strength } \\
(\mathrm{MPa})\end{array}$ & $\begin{array}{c}\text { Density } \\
\left(\mathrm{g} / \mathrm{cm}^{3}\right)\end{array}$ \\
\hline PVA & 39 & 12 & 40 & 1,600 & 1.30 \\
PE & 75 & 15 & 12 & 2,500 & 0.97 \\
\hline
\end{tabular}

Table 4 The combined volume fraction of hybrid fibers

\begin{tabular}{c|c|c}
\hline \hline & \multicolumn{2}{|c}{ Volume fraction of hybrid fibers(\%) } \\
\cline { 2 - 3 } & PVA & PE \\
\hline Mix 1 & 1.0 & 0.5 \\
Mix 2 & 1.0 & 1.0 \\
Mix 3 & 1.5 & 0.5 \\
Mix 4 & 1.75 & 0.25 \\
\hline
\end{tabular}

\subsection{HFSLCC의 설계}

기존의 연구[12]에 의하면 섬유복합재료의 인성비(toughness ratio, $R_{T}$ )가 높을수록 안정적인 변형률 경화거동을 나타내며, 최소한 3.0 이상이어야 변형률 경화거동이 발생할 수 있는
것으로 밝혀진 바 있다. 따라서 본 연구에서는 되도록 높은 인성비를 갖고 있는 HFSLCC를 설계하고자 계획하였다. 인 성비는 식 (6)과 같이 섬유 가교 곡선 분석을 통하여 계산된 $J_{b}^{\prime}$ 와 매트릭스 파괴인성 실험을 통하여 얻은 $J_{t i p}$ 의 비율로 정의된다.

$$
R_{T}=\frac{J_{b}^{\prime}}{J_{t i p}}
$$

먼저 $J_{b}^{\prime}$ 를 계산하기 위하여 Table 5 에 나타낸 바와 같이 섬유인발 실험을 통하여 물과의 정전기적인 인력으로 발생되 는 화학적 부착 계수 $G_{d}$ 와 시멘트 매트릭스와 섬유사이의 마찰 계수인 $\tau_{0}$ 를 구하였다. 2가지 변수들은 마이크로역학에 의하여 섬유 가교 특성을 예측-평가하는데 필요한 섬유-시멘 트 매트릭스의 경계 특성을 나타내는 주요 변수이며, 식 (4) 에 대입함으로써 Fig. 7과 같이 섬유 혼입률에 따른 섬유 가 교 곡선을 구할 수 있다.

Table 5 Results of single fiber pull-out test

\begin{tabular}{c|c|c}
\hline \hline & $\begin{array}{c}\text { Frictional bond }\left(\tau_{0}\right) \\
(\mathrm{MPa})\end{array}$ & $\begin{array}{c}\text { Chemical bond }\left(G_{d}\right) \\
\left(\mathrm{J} / \mathrm{m}^{2}\right)\end{array}$ \\
\hline PVA & 1.83 & 1.85 \\
PE & 0.63 & 0 \\
\hline
\end{tabular}

Table 6 Fiber bridging curve analysis

\begin{tabular}{c|c|c|c}
\hline \hline & $\begin{array}{c}J_{b}^{\prime} \\
\left(\mathrm{J} / \mathrm{m}^{2}\right)\end{array}$ & $\begin{array}{c}\sigma_{0} \\
(\mathrm{MPa})\end{array}$ & $\begin{array}{c}\sigma_{f c} \\
(\mathrm{MPa})\end{array}$ \\
\hline PVA 2\%-PE 0\% & 248.4 & 5.3 & 2.9 \\
Mix 1 & 269.1 & 4.8 & 3.3 \\
Mix 2 & 392.1 & 6.7 & 2.9 \\
Mix 3 & 320.5 & 5.9 & 3.1 \\
Mix 4 & 278.2 & 5.7 & 2.9 \\
\hline
\end{tabular}

하이브리드 섬유 혼입률에 따른 섬유 가교 곡선 분석의 결과로 도출할 수 있는 보상에너지 $J_{b}^{\prime}$ 와 섬유로 전달되는 최대 가교응력 $\sigma_{0}$ 및 인장 균열응력 $\sigma_{f c}$ 등의 특성을 Table 6 에 나타내었다. 섬유 가교 곡선 분석결과 $\mathrm{PE}$ 섬유의 혼입률 이 증가함에 따라 $J_{b}^{\prime}$ 와 $\sigma_{0}$ 가 증가하여 섬유를 통하여 전달 되는 에너지와 응력이 향상됨을 알 수 있으며, 단일 PVA섬 유를 사용한 경우보다 $\mathrm{PE}$ 섬유가 혼입된 하이브리드 섬유를 사용한 경우가 섬유 가교 특성이 향상됨을 알 수 있었다. 또 한 파괴인성 실험을 통하여 도출된 물-시멘트비와 glass bubble의 혼입률에 따른 시멘트 매트릭스의 $K_{m}$ 과 $E_{c}$ 를 식 (2)에 대입하고 $J_{t i p}$ 을 계산하여 Table7에 나타내었다. $J_{t i p}$ 을 구함으로써 HFSLCC의 시멘트 매트릭스에 추가적으로 균열 


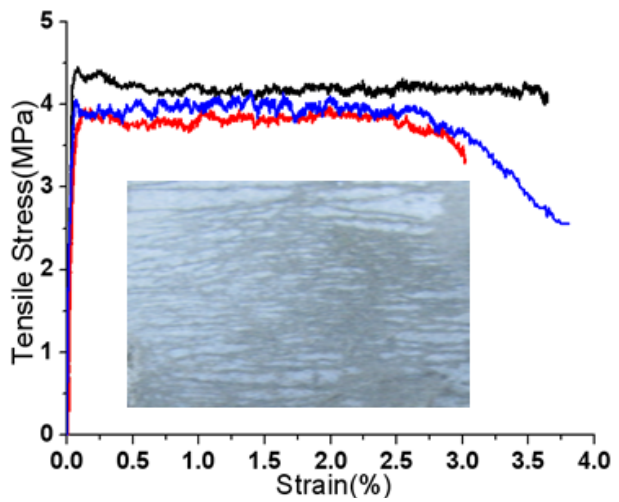

(a) HFSLCC I

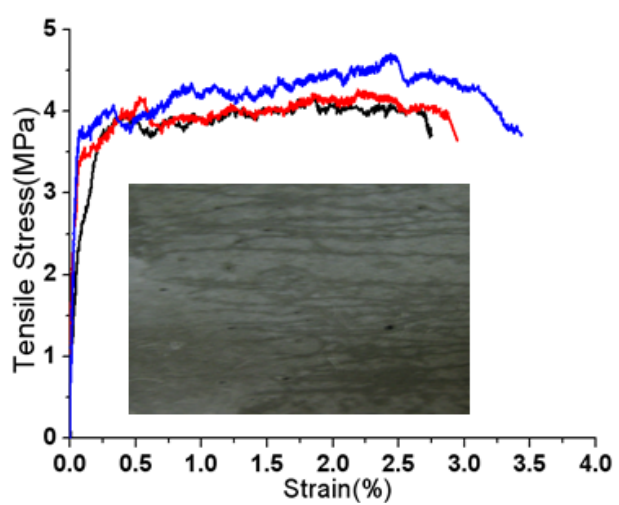

(c) HFSLCC III

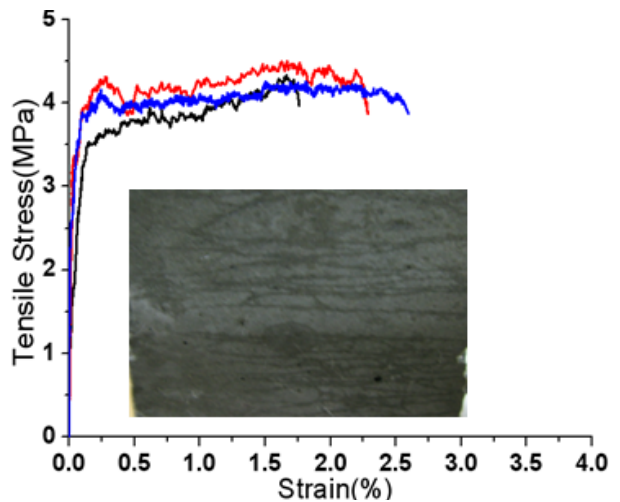

(b) HFSLCC II

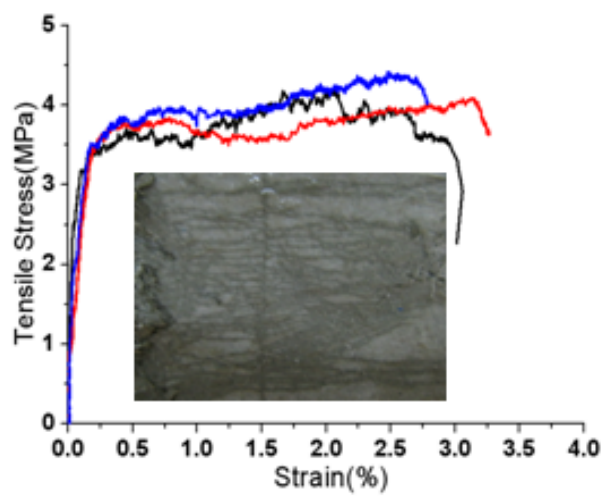

(d) HFSLCC IV

Fig. 8 Uniaxial tensile stress-strain curve according to mixture proportions.

이 발생되기 위한 에너지를 구할 수 있으며, 최종적으로 $J_{b}^{\prime}$ 와의 비율인 인성비를 도출하여 에너지 조건을 평가하였다. 인성비 평가를 위하여 4가지로 설정한 섬유 혼입률에 대하여 $J_{b}^{\prime}$ 가 $269.1 \mathrm{~J} / \mathrm{m}^{2}$ 로 가장 작은 $\mathrm{Mix} 1$ 을 기준으로 설정하여 $J_{t i p}$ 과의 비율을 Table 7에 나타내었다. 모든 배합이 3.0 이상 의 충분한 인성을 확보하여 에너지 조건을 만족함을 알 수 있으며, $\sigma_{0}$ 가 $\sigma_{f c}$ 보다 큰 것으로 예측되어 강도 조건 역시 만족함을 알 수 있어 4가지 배합의 HFSLCC가 직접인장 실 험을 실시하기 전에 안정적인 변형률 경화거동과 다수의 미 세균열 특성이 나타날 것으로 예상되었다.

Table 7 Toughness ratio

\begin{tabular}{c|cc|cc}
\hline \hline & \multicolumn{2}{|c|}{$J_{\text {tip }}\left(\mathrm{J} / \mathrm{m}^{2}\right)$} & \multicolumn{2}{c}{$\begin{array}{c}\text { Toughness ratio } \\
\text { (Mix 1 기준) }\end{array}$} \\
\hline $\mathrm{GB} / \mathrm{C}$ & $\mathrm{W} / \mathrm{C}=45 \%$ & $\mathrm{~W} / \mathrm{C}=55 \%$ & $\mathrm{~W} / \mathrm{C}=45 \%$ & $\mathrm{~W} / \mathrm{C}=55 \%$ \\
\hline $15 \%$ & 5.29 & 4.52 & 50.9 & 59.5 \\
$25 \%$ & 3.99 & 2.65 & 67.4 & 101.5 \\
$35 \%$ & 2.76 & 1.76 & 97.5 & 152.9 \\
\hline
\end{tabular}

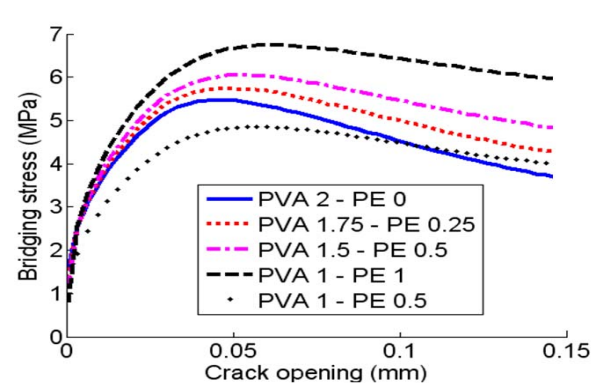

Fig. 7 The fiber bridging curves according to combined volume fraction of hybrid fibers.

특히, 전체 섬유 혼입률 $1.5 \%$ 인 Mix 1 은 타 배합설계에 비하여 섬유 혼입률을 감소시킬 수 있어 HFSLCC의 비빔성 능을 확보함과 동시에 $\mathrm{PE}$ 섬유의 사용으로 우수한 인장특성 이 발휘될 것이라고 예상된다. 따라서 Mix 1이 HFSLCC의 4가지 배합에서 에너지 조건, 강도 조건, 인성비, 시공성을 평가해 볼 때 가장 효율적인 하이브리드 섬유 혼입률인 것으 로 평가할 수 있다. 
Table 8 Mixture proportions of HFSLCC detemined based on micromechanical design

\begin{tabular}{|c|c|c|c|c|c|c|c|c|c|c|c|}
\hline & \multirow{2}{*}{$\begin{array}{l}\text { W/C } \\
(\%)\end{array}$} & \multirow{2}{*}{$\begin{array}{c}\text { GB/C } \\
(\%)\end{array}$} & \multirow{2}{*}{$\mathrm{C}$} & \multirow{2}{*}{$\mathrm{W}$} & \multirow{2}{*}{$\mathrm{S}$} & \multirow{2}{*}{ Slag } & \multirow{2}{*}{ GB } & \multirow{2}{*}{ HPMC } & \multirow{2}{*}{ PCSP } & \multicolumn{2}{|c|}{ Hybrid fiber(\%) } \\
\hline & & & & & & & & & & PVA & $\mathrm{PE}$ \\
\hline HFSLCC I & 50 & 25 & 1.0 & 0.5 & 0.8 & 0.25 & 0.25 & 0.004 & 0.010 & 1.0 & 0.5 \\
\hline HFSLCC II & 50 & 25 & 1.0 & 0.5 & 0.8 & 0.25 & 0.25 & 0.004 & 0.015 & 1.0 & 1.0 \\
\hline HFSLCC $\mathbb{I I}$ & 50 & 25 & 1.0 & 0.5 & 0.8 & 0.25 & 0.25 & 0.004 & 0.015 & 1.5 & 0.5 \\
\hline HFSLCC IV & 50 & 25 & 1.0 & 0.5 & 0.8 & 0.25 & 0.25 & 0.004 & 0.015 & 1.75 & 0.25 \\
\hline
\end{tabular}

C : Cement, W : Water, S : Silica sand, GB : Glass bubble, PCSP : Polycarboxylate super-plasticizer, HPMC : Hydroxypropylmethyl-cellulose.

* All numbers are mass ratios of cement weight except for hybrid fibers(volume fraction).

한편 물-시멘트비가 높아지고 glass bubble의 혼입량이 증 가할수록 $J_{t i p}$ 이 감소하여 인성비가 커지는 것을 알 수 있다. 이러한 결과는 균열발생에 필요한 에너지가 시멘트 매트릭스 의 강도저하로 인하여 감소되었기 때문이라 판단되며, 물-시 멘트비 $55 \%$ 에 glass bubble 혼입률이 $35 \%$ 일 경우가 다중 균 열발생에 가장 유리한 조건이라고 할 수 있다. 하지만 파괴 인성 실험을 위하여 시멘트 매트릭스를 제조할 때 물-시멘트 비가 $55 \%$ 인 경우 glass bubble의 혼입률이 $35 \%$ 이면 시멘트 페이스트 와 glass bubble의 재료분리현상이 발생하여 비빔성 능이 크게 저하되었으며, 물-시멘트비가 $45 \%$ 인 경우 glass bubble의 혼입률이 $35 \%$ 이면 시멘트 매트릭스의 유동성 확보 를 위하여 고성능 감수제가 시멘트량의 $5 \%$ 까지 과다 사용되 어 균질한 재료확보에 어려움이 있었다.

따라서 HFSLCC의 최적 시멘트 매트릭스 제조를 위하여 경 제성과 비빔성능을 고려하면서 역학적 특성을 만족시킬 수 있는 물-시멘트비는 $50 \%$ 로 결정하였고, glass bubble 첨가량은 재료분 리와 비빔성능을 고려하여 시멘트 질량의 $25 \%$ 로 결정하였다.

\section{4. 성능 평가}

\section{1 직접인장성능}

마이크로역학 설계방법으로 4 가지 하이브리드 섬유 혼입률에 따른 HFSLCC의 배합설계를 수행한 결과는 Table 8에 나타낸 바와 같다. 여기서, $\mathrm{HPMC}$ 와 PCSP의 양은 비빔시험을 통하여 최적의 유동성과 섬유분산성을 나타낼 수 있도록 결정하였다. HFSLCC의 인장성능을 파악하기 위하여 3 개의 실험체에 대하 여 직접인장 실험을 수행하였고, 그 결과로 얻은 응력-변형률 관계와 1 축 인장 하에서 발생한 균열의 패턴을 Fig. 8에 나타 내었다. 4종류의 HFSLCC 실험체는 1 축 인장하에서 첫 균열이 발생한 후 변형률 경화구간에서 미세균열의 발생과 함께 최소 $2.0 \%$ 이상의 인장 변형률을 나타내어 일반 콘크리트의 변형률 $0.01 \%$ 에 비하여 약 200 배 이상 높은 변형능력을 나타내었다.

한편, 직접인장 실험의 종료는 더 이상 변형률 경화거동을 보이지 않으며 하나의 균열에 응력이 집중되어 균열이 폭이 증 가하여 최종적으로 실험체가 파괴되었을 때를 기준으로하였다. 이때 초기 균열응력은 직접인장 실험시 인장하중이 증가하다가
실험체에 균열이 발생하여 하중저하가 발생되는 시점의 응력으 로 평가하였으며, 최대 인장응력은 HFSLCC 실험체가 변형률 경화 거동을 하는 구간에서 측정되는 최대 인장응력으로 또한 이에 상응하는 변형률을 최대 변형률로 결정하여 Table 9에 각 각의 배합에 따른 3 개의 실험체의 평균값을 나타내었다. Table 9에서 확인할 수 있듯이 LHFSLCC I IV 배합에서 직접인장 실험을 통하여 측정된 $\sigma_{0}$ 가 4.2 4.5MPa로 2.6 3.0MPa로 측정 된 $\sigma_{f c}$ 보다 큰 값을 나타내므로 강도 조건을 만족함을 알 수 있었다.

따라서 시멘트 매트릭스-섬유의 경계특성과 시멘트 매트릭 스 파괴특성을 파악하여 에너지 조건과 강조 조건을 평가함으 로서 변형률 경화거동과 다중균열을 예측하는 마이크로역학 설 계방법을 직접인장 실험으로 평가해본 결과 실제적으로 2 가지 조건을 충족시키며 변형률 경화거동과 다중균열이 발생하는 것 을 알 수 있어 HFSLCC를 개발하기 위한 타당한 설계방법임을 알 수 있다.

한편, 섬유 혼입률이 $1.5 \%$ 인 HFSLCC I 의 배합이 전체 섬 유 혼입률 $2.0 \%$ 인 나머지 배합과 비교해 볼 때 최소의 섬유 혼입량으로도 대등한 인장 변형률 성능을 나타내어 개발된 HFSLCC의 배합 중 가장 효율적인 배합이라고 할 수 있다. 하 지만 PE섬유 혼입률이 $1.0 \%$ 로 가장 많은 HFSLCC II 의 배합 이 인성비 평가의 결과로서는 변형성능이 가장 우수해야 하지 만 실험결과 상대적으로 작은 변형률을 나타내었는데, 그 이유 는 소수성 $\mathrm{PE}$ 섬유의 과다 혼입으로 시멘트 매트릭스 내에서 효과적인 분산이 잘 일어나지 않아 섬유뭉침 현상이 발생되었 기 때문이라 사료되며 이를 검증하기 위해서는 김 등[13]이 제 안한 형광 원리와 이미지 프로세싱 기법을 통한 정량적인 섬유 분산성 평가에 관한 연구가 향후에 필요할 것으로 판단된다.

Table 9 Tensile properties of HFSLCC (average values)

\begin{tabular}{c|c|c|c}
\hline \hline Specimens & $\begin{array}{c}\text { First } \\
\text { cracking stress } \\
\text { (MPa) }\end{array}$ & $\begin{array}{c}\text { Ultimate } \\
\text { tensile stress } \\
\text { (MPa) }\end{array}$ & $\begin{array}{c}\text { Ultimate } \\
\text { strain } \\
\text { (\%) }\end{array}$ \\
\hline HFSLCC I & 2.9 & 4.2 & 3.0 \\
HFSLCC II & 3.0 & 4.5 & 2.0 \\
HFSLCC III & 2.8 & 4.4 & 2.5 \\
HFSLCC IV & 2.6 & 4.3 & 2.7 \\
\hline
\end{tabular}


따라서 PVA섬유와 PE섬유를 하이브리드 할 경우 PE섬유는 전체 섬유 혼입률 $2 \%$ 중에서 $25 \%$ 이하의 범위가 섬유 분산 성을 확보하면서 탄성계수, 인장강도 등의 물리적 특성이 최 대한 발휘될 수 있는 최적 혼입량이라고 사료된다.

\subsection{HFSLCC의 단위용적질량 및 압축강도}

HFSLCC의 경량성과 압축강도 결과를 Table 10 에 나타내 었다. 실험결과 HFSLCC I IV 배합의 실험체는 단위질량 $1,660 \sim 1,710 \mathrm{~kg} / \mathrm{m}^{3}$ 범위에서 약 57 59MPa의 압축강도를 나타 내기 때문에 고강도와 경량성이 요구되는 주요부재에 충분히 적용할 수 있을 것으로 판단된다.

Table 10 Density and compressive strength test results

\begin{tabular}{c|c|c}
\hline \hline Specimens & $\begin{array}{c}\text { Bulk density } \\
\left(\mathrm{kg} / \mathrm{m}^{3}\right)\end{array}$ & $\begin{array}{c}\text { Comp. strength } \\
\text { (MPa) }\end{array}$ \\
\hline HFSLCC I & 1,660 & 57.03 \\
HFSLCC II & 1,680 & 56.54 \\
HFSLCC II & 1,690 & 59.06 \\
HFSLCC IV & 1,710 & 58.96 \\
\hline
\end{tabular}

\section{5. 결 론}

이 연구에서는 HFSLCC를 개발하기 위하여 마이크로역학 과 안정상태 균열이론의 설계방법 및 기본 재료실험을 통하 여 4 가지 가능한 배합을 결정하였고, 직접인장 실험과 압축 강도 및 단위용적질량 시험을 수행하여 HFSLCC의 성능을 평가하여 얻은 결론은 다음과 같다.

1) 마이크로역학과 안정상태 균열이론을 바탕으로 HFSLCC 를 개발하기 위하여 사용재료를 선정하고 최적 혼입률을 결정하여 물-시멘트비 $50 \%$ 와 Glass bubble 및 고로슬래 그 미분말을 각각 시멘트 질량의 $25 \%$ 로 첨가한 시멘트 매트릭스 최적배합을 제시하였다.

2) 변형률 경화거동을 보이는 HFSLCC를 설계하기 위하여 4 가지 하이브리드 섬유 혼입률 조건에 따른 섬유 가교 거동 분석을 통하여 $J_{b}^{\prime}$ 를 도출하였고, 시멘트 매트릭스 파괴인성 실험을 통하여 $J_{t i p}$ 을 도출하여 인성비를 평가 한 결과 모든 배합이 3.0 이상의 결과를 나타내어 변형 률 경화거동을 발휘할 수 있는 조건을 만족하였다.

3) HFSLCC의 인장특성을 평가하기 위하여 직접인장 실험 을 실시한 결과 뚜렷한 변형률 경화거동의 특성과 함께 다중균열이 발생하였으며, 최소 $2.0 \%$ 이상의 인장 변형 률을 나타내어 고인성의 특성을 발휘하였다.

4) PVA섬유 $1.0 \%, \mathrm{PE}$ 섬유 $0.5 \%$ 의 HFSLCC배합이 가장 최소의 섬유 사용으로 우수한 인장변형 성능을 나타내어 HFSLCC 배합 중에서 시공성, 경제성 측면에서 가장 효 율적인 배합으로 나타났다.
5) HFSLCC는 경량 충진재 Glass bubble을 첨가하여 고인 성의 특성과 함께 $1,660 ~ 1,710 \mathrm{~kg} / \mathrm{m}^{3}$ 범위의 단위용적질 량과 57 59MPa의 압축강도를 나타냄으로써 콘크리트 구조물 주요부재에 적용할 경우 인장하중 전달능력 및 에너지 흡수능력을 향상시킬 수 있을 것이라 판단된다.

\section{후 기}

이 연구는 2008년도 정부(과학기술부)의 재원으로 한국과학 재단(2008-0059161)에서 지원하는 연구과제로 수행된 것이며, 이에 대해 진심으로 감사드립니다.

\section{참고문헌}

1) 홍건호, 김기수, 한복규, “건설분야의 섬유강화 시멘트 복합 신재료,” 한국복합재료학회지, 제 19 권 제 1 호, 2006, pp. 43-48.

2) Kok Seng Chia, Min-Hong Zhang, "Water permeability and chloride penetrability of high-strength lightweight aggregate concrete," Journal of Cement and Concrete Reserch 32, 2002, pp. 639-645.

3) T.Y. Lo, A. Vadeem, W.C.P. Tang, P.C. Yu, "The effect of high temperature curing on the strength and carbonation of pozzolanic structural lightweight concretes," Journal of Construction and building Materials 23, 2009, pp. 13061310.

4) Bing Chen, Juanyu Liu, "Contribution of hybrid fiber on the properties of the high-strength lightweight concrete having good workability," Journal of Cement and Concrete Reserch, 35, 2006, pp. 913-917.

5) 이행기, 송수용, “섬유 혼입률에 따른 섬유보강 경량골재 콘크리트의 역학적 특성,” 한국콘크리트학회 논문집, 제 18권 제6권, 2006, pp. 743-748.

6) V.C. Li, Shuxin Wang and Cynthia Wu, "Tensile StrainHardening Behavior of PolyvinylAlcohol Engineered Cementitious Composite (PVA-ECC),” ACI Material Journal, Vol. 98, No.6, 2001, pp. 483-492.

7) 박대효, 노명현, 박춘근, “광물혼화재가 혼입된 다성분 페이스트 시스템의 레올로지 특성평가,” 한국콘크리트학 회 논문집, 제 16 권 제 2 호, 2004 , pp. 241-248.

8) 김윤용, 김정수, 하기주, 김진근, “고로슬래그 미분말이 혼입된 ECC (Engineered Cementitious Composite)의 개발," 한국콘크리트학회 논문집, 제18권 제1호, 2006, pp. 21-28.

9) Z. Lin, T. Kanda, and V. C. Li, "On interface property characterization and performance of fiber-reinforced cementitious 
composites," Concrete Science and Engineering, 1, 1999, pp. 173-184.

10) 김윤용, “시멘트계 모르타르 매트릭스를 활용한 섬유복합 재료 ECC (Engineered Cementitious Compioste)의 설계와 시공 성능,” 한국복합재료학회지, 제20권 제2호, 2007, pp. 21-26.

11) Michael D. Lepech, Victor C. Li, "Design of Green Engineered Cementitious Composites for Improved Sustainability," ACI Material Journal, Vol. 105, No. 6, 2008, pp. 567-575.

12) T. Kanda, and V.C. Li, "Interface Property and Apparent Strength of a High Strength Hydrophilic Fiber in Cement Matrix," ASCE J. Materials in Civil Engineering, Vol. 10, No. 1, 1998, pp. 5-13.

13) 김윤용, 이방연, 김정수, 김진근, “이미지 프로세싱 기법을 이용한 섬유복합재료의 정량적인 섬유분산성 평가,” 한국 비파괴검사학회지, 제27권 제2호, 2007, pp. 148-156. 